Ann. Zootech., 1980, 29, no h. s., 17-26.

\title{
Survey of the energy feeding standards used in the COST countries and of the experimental background
}

\author{
A. NEIMANN-SøRENSEN \\ National Institute of Animal Science \\ 25 Rolighedsvej, DK-1958 Copenhagen V (Denmark)
}

\begin{abstract}
Résumé
Etude des apports énergétiques recommandés dans les différents pays de la communauté économique européenne et dans les pays associés
\end{abstract}

Les recommandations énergétiques et les modes de calculs de la valeur énergétique des aliments des 12 pays sont examinés et comparés par l'auteur.

Pour déterminer la valeur énergétique des aliments, l'énergie métabolisable est utilisée, comme mode d'expression final dans trois pays, et comme élément de calcul de l'énergie nette dans trois autres pays. Quatre pays utilisent l'unité amidon et deux autres des unités fourragères (FFU et SFU), en calculant dans tous les cas la valeur énergétique nette des aliments à partir de leur composition chimique, mais avec différents coefficients et facteurs de corrections. Trois pays viennent d'introduire de nouveaux systèmes fondés sur les mêmes bases dans lesquels l'énergie nette est calculée en multipliant l'énergie métabolisable par un coefficient $\mathbf{K}$ exprimant le rendement de l'utilisation de l'énergie métabolisable pour l'entretien et pour diverses productions. Ces systèmes tiennent aussi compte du niveau de production de l'animal.

Les recommandations énergétiques sont données en fonction du poids, généralement du gain de poids, parfois en fonction du type d'animal (mâle, femelle, castré, animaux jeunes ou âgés) et dans deux pays en fonction de la race. Dans quatre pays les recommandations sont issues d'études métaboliques, en chambres respiratoires, éventuellement corrigées par des essais en lots; dans les autres, elles ont été calculées à partir d'essais d'alimentation. Dans le premier cas, les besoins d'entretien sont estimés uniquement en fonction du poids vif, et les données sur la quantité d'énergie déposée dans le gain demeurent assez rares et difficiles à généraliser. On peut tenir compte à la fois des essais d'alimentation et des données analytiques disponibles.

Des systèmes nombreux et plus ou moins anciens sont donc en usage et un effort d'harmonisation à la fois sur les bases utilisées et les modes d'expression mérite d'être entrepris. 


\section{Introduction}

For more than one hundred years animal scientists have attempted to devise systems which would permit farmers to compute rations for their cattle which would supply the nutrients necessary for maintenance, growth and milk production. The systems consist of two parts : 1. tables showing the composition, digestible nutrients and estimated feeding value of the various feeds ; 2 . statements of the nutrient requirements of animals of different size, age and condition, when growing, fattening or milking at different rates.

The long history of this area of animal science has contributed in many ways to our understanding of the physiological pathways along which the cattle utilise their food for growth and milk production. As a consequence of this, continuous improvements have been made in assessment of feeding standards and description of methods for calculating the nutritive value of feeds. Nevertheless, it is probably true to say that, even today, there is still a surprising lack of conformity between countries. Different methods - many of them quite complicated and not interconvertible - are in use in the various countries. This is deplorable, because the possession of well-founded feed evaluation methods and feeding standards are fundamental to essential functions in animal production : a. the optimal and economic use of the feed resources ; b. proper pricing of the commercial feeds according to their nutritional value; c. effective control of the commercial feeds and, $d$. utilisation and full benefit of scientific papers between the countries.

It is against this background that The Nutrition and Management Working Group, under the EEC programme of research on beef production, recommended to the beef committee that the present seminar should be held. The proposal was accepted and it was decided that the participation should be extended to all COST-countries.

In order to have a solid and realistic base for the deliberations and discussions of the seminar, it was decided by the planning committee that each country should provide a short description of the standards used in the country and of the experimental background. In order to demonstrate the pratical consequences of the use of the various standards, each country was also asked to estimate daily gains in bulls, steers and heifers fed five different rations at 200 and $400 \mathrm{~kg}$ liveweight respectively.

As far as the energy standards are concerned I shall try, in the following, to give a comparative survey of the descriptions received while, subsequently, Dr. RefsgaARD Andersen will give an analysis of the results which have come out of the application of the standards to the identical situations as described.

\section{Material}

Descriptions of energy standards and methods for calculating the energy value of feeds were received from 12 countries : Belgium, Denmark, Finland, France, Greece, Holland, Ireland, Yugoslavia, Sweden, Switzerland, United Kingdom and West Germany. Few countries use the same systems or units for evaluation of the energy value of feeds and for the calculation of the feed requirement of the animals. Between some countries there are great similarities, but even in these cases they make use of a different terminology and parameters. 
In order to facilitate understanding of the background of the different systems and to further the conversion from one to another (where possible) a list of symbols and abbrevations is given.

\section{Terminology and parameters}
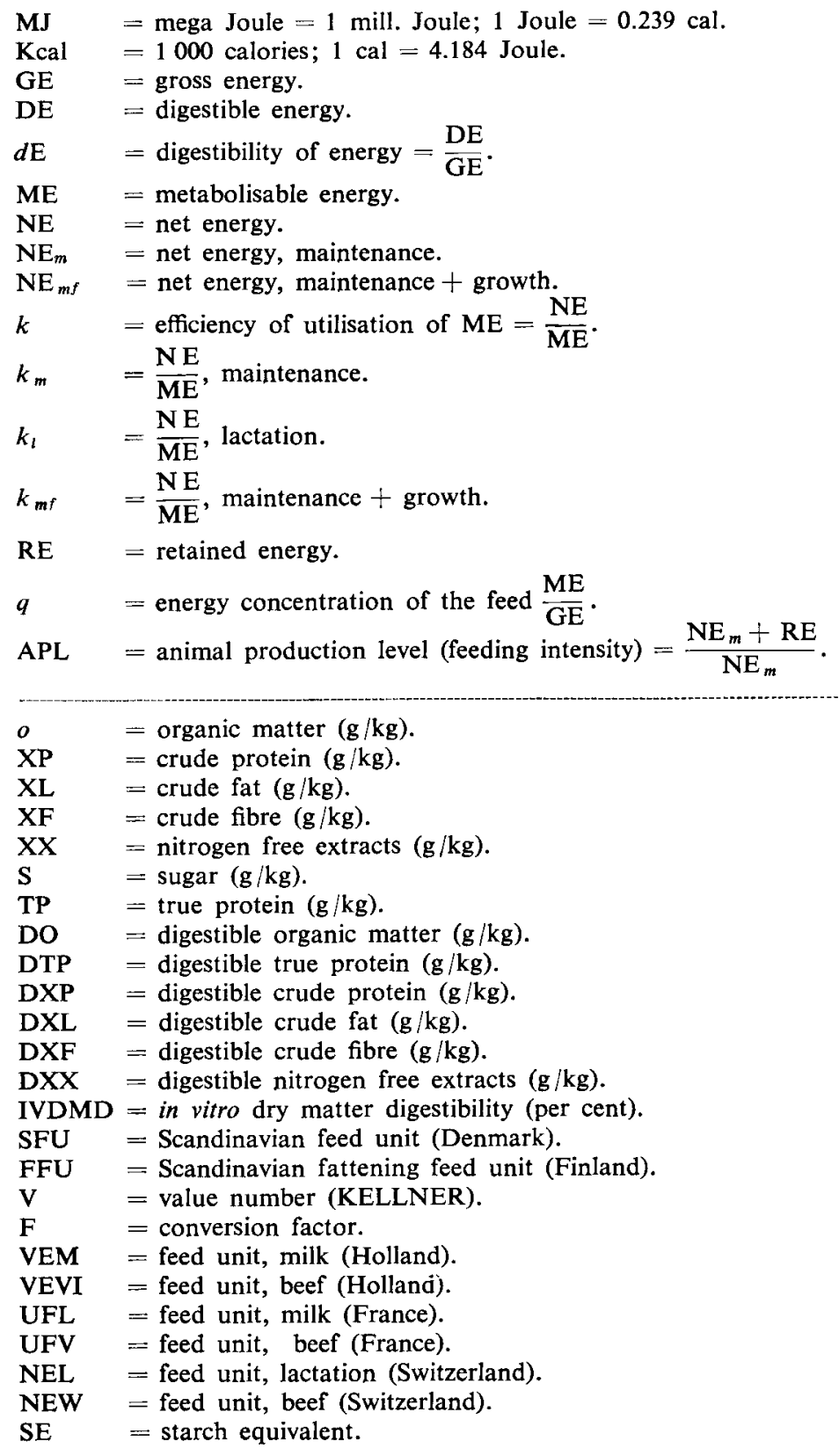


\section{Estimation of the energy values of feeds}

The descriptions which were received were, in many cases, scarce and for the following discussion, therefore, they were supplemented by information taken from STEG and HoNIG (1979). As a general background Figure 1 is presented illustrating the utilisation of energy in ruminants. It shows some of the more important parameters and their typical variations.

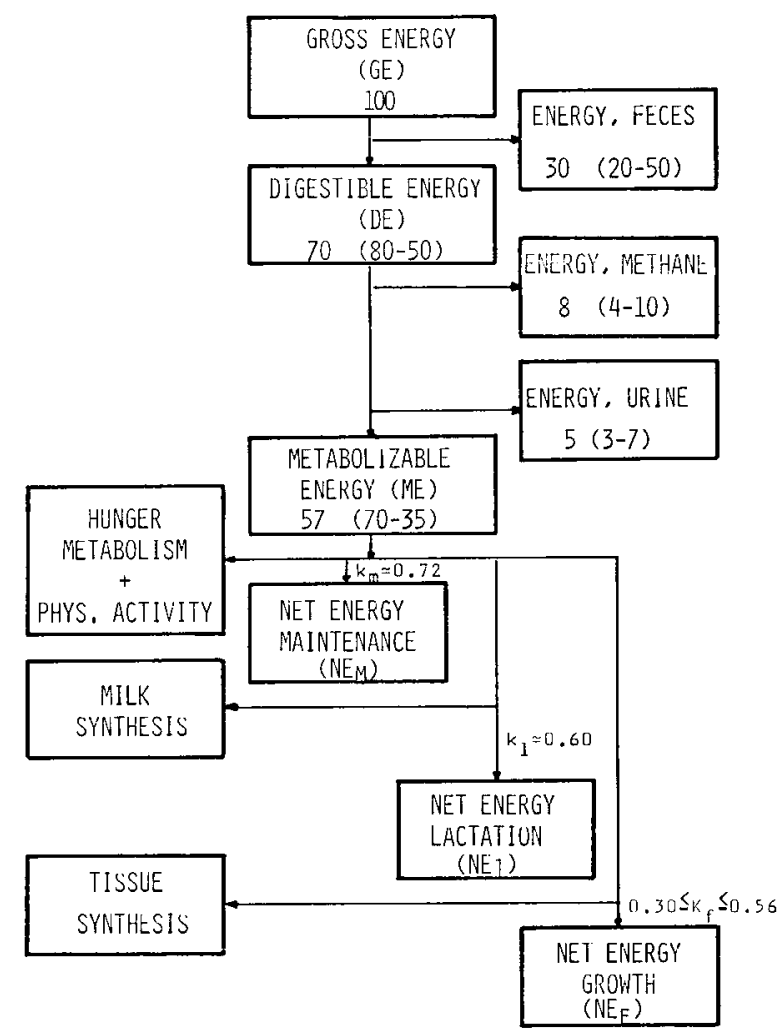

FIG. 1. - The utilization of energy in ruminants.

\section{Metabolisable energy (ME)}

There are three countries in which the energy values are expressed as ME: UK, Ireland and Sweden. In three other countries ME is used as an intermediate : France, Holland and Switzerland. Table 1 presents, in a compressed form, the methods used in the various countries to calculate the ME contents of feeds. It is seen that several of the factors used vary from country to country, which implies that the feeds will be evaluated differently. The greatest differences appear in the multiplication factor for digestible crude fat. As to the three countries, Holland, Switzerland and France, which have recently introduced new common 
systems, the metabolisable energy is calculated in the same way in Switzerland and Holland, the only difference being that it is expressed in feed units (on basis of calories) in Holland, but in MJ in Switzerland. In France the content of metabolisable energy is calculated differently.

\section{Starch equivalents (SE)}

Four of the reporting countries, West Germany, Yugoslavia, Greece and Belgium, use the SE-system which is a net energy system ; the information received was not very detailed but it appears, from Table 1, that there are other differences between the methods applied. In Belgium the SE content in roughages is calculated from the content of digestible organic matter corrected according to the content of protein and crude fibre. For concentrates a very high fat factor is used and there is a special factor for sugar content. A similar correction is used in Yugoslavia. Yugoslavia, West Germany and Greece make use of the classical crude fibre correction according to KELLNER, but it is applied in slightly different forms in each country.

\section{Feed units (SFU, FFU)}

As seen from table 1, the basic principle for calculation is the same for feed units and starch equivalents. The main difference between SFU and FFU lies in the use of the protein factors 1.43 and 0.94 respectively, and in the factor $F$ which converts the 'milk production value' (SE) into feed units. An important aspect in evaluating these two systems relates to the use of the value number $V$. This is assessed from group experiments with feed substitutions and, therefore, $\mathrm{V}$ will tend to make corrections for any shortcomings of the intermediate energy value precalculated on the basis of contents of digestible nutrients. Since these experiments are not the same between countries, V may vary from the one country to the other.

\section{New net energy systems (VEM and VEVI ; NEL and NEW ; UFL and UFV)}

These three systems have recently been introduced in Holland, Switzerland and France respectively. They are net energy systems and the net energy is calculated from the metabolisable energy by multiplication with the factor $k$, which expresses the efficiency by which ME is utilised for maintenance and production. The systems also correct for the effect of the animal production level (APL) which is an expression of the feeding intensity. By introduction of this correction, the systems take account of the repeated findings that an increase in the level of feeding is accompanied by a decrease in the digestibility, which is only partially compensated for by a reduction in the urinary and methane energy losses. The digestibility depression with the increase in feeding level will also be dependent on the quality of the feed and will be most pronounced for feeds with a high content of cell wall substances.

These associated effects are not unimportant, but they must be balanced against the simplicity and applicability of the systems in practice. Such considerations have led to the use of a fixed APL value of 1.5 in the systems. To counteract the errors arising from this simplification and improve the correlation 


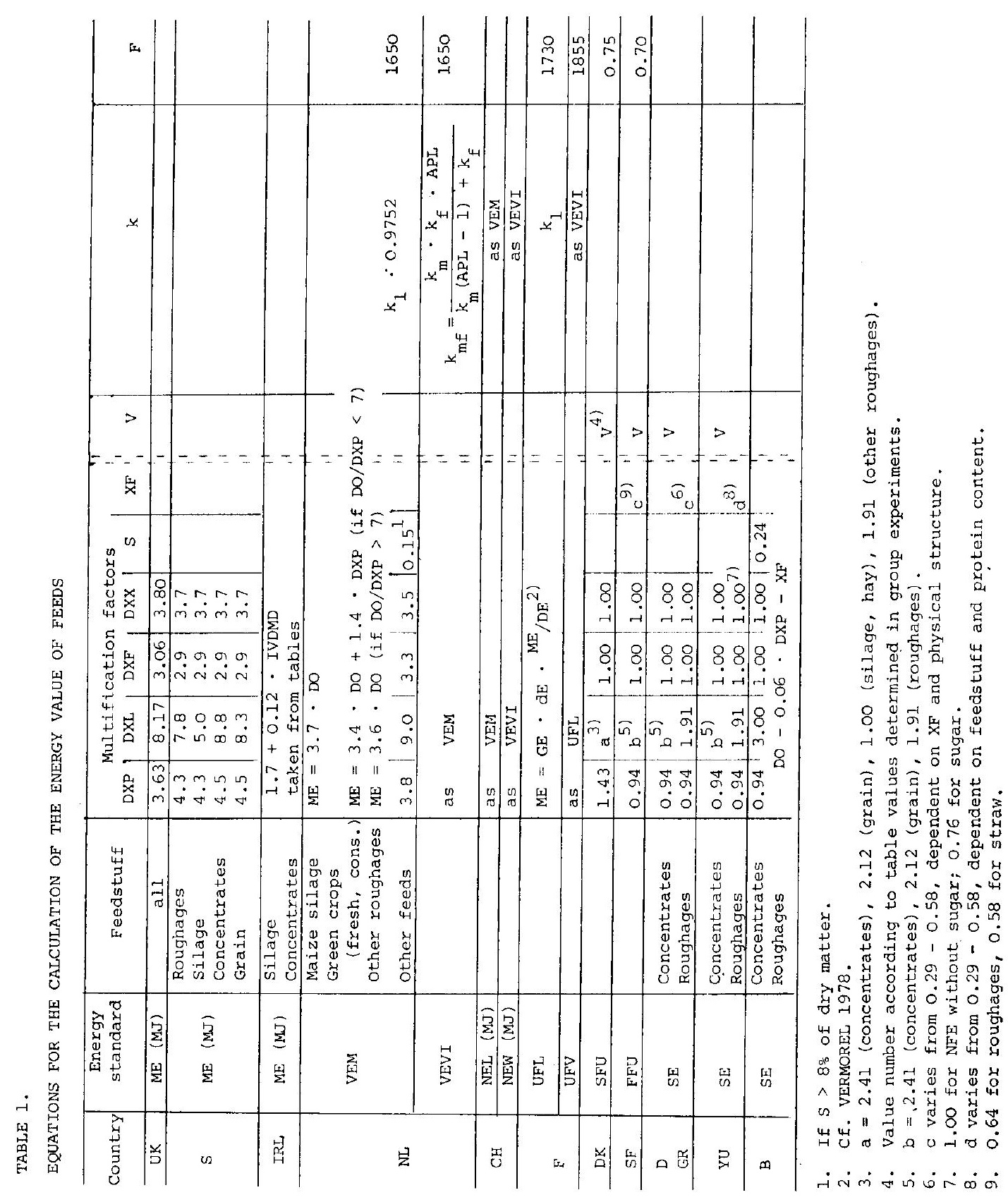


with the findings from practical experiments, some corrections are made in the setting up of the feeding standards.

In the systems the $k$ factors are calculated as follows:

$$
\begin{aligned}
& k_{m}=0.554+0.287 q \\
& k_{f}=0.006+0.78 q \\
& k_{l}=0.60+0.24 \quad(q-0.57)
\end{aligned}
$$

The graphs in figure 2 show the relationships. It should be added that the utilisation for the metabolisable energy for maintenance + growth, $k_{m f}$, is determined with a low degree of accuracy.

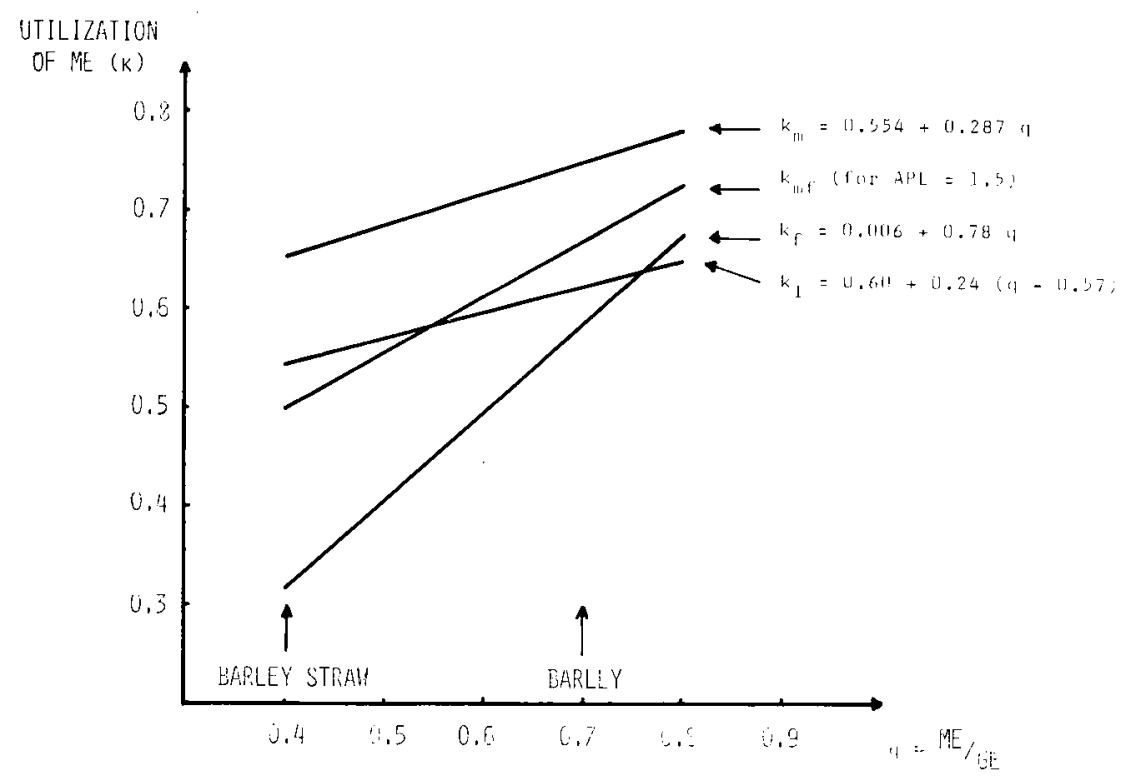

FIG. 2. - Utilisation of the metabolisable energy for maintenance $\left(k_{m}\right)$, lactation $\left(k_{l}\right)$, fattening $\left(k_{f}\right)$. and maintenance + growth $\left(k_{m f}\right)$ as a function of the energy concentration of the feed $(q)$.

\section{Energy standards}

It goes without saying that the energy value of the feeds and energy requirement of animals must be expressed in the same units. A survey of information received from the various countries is presented in table 2 . While all countries have standards specified according to the weight of the animal, there are a few countries which do not give norms according to the rate of growth in a specified form. Separate norms for the different categories of animals have only been introduced in the different countries to a varying degree. The situation seems to be a reflection of the importance of the categories in the various countries. Only France and Sweden have norms specified to breeds. The experimental background for assessing the standards seems to be quite different from country to country. Thus the norms, in Holland, UK, Ireland and Sweden, are based mainly 
on metabolic experiments, eventually corrected according to results from feeding trials. In other countries, like Switzerland, Denmark and France, the standards are founded on feeding experiments.

When the norms are based on metabolic experiments, a distinction is made between requirement for maintenance and requirement for growth :

$$
\begin{aligned}
& \text { Energy requirement }(\mathrm{NE})=\mathrm{ME}_{m} \cdot k_{m}+\mathrm{RE} \\
& \text { Energy requirement }(\mathrm{ME})=\mathrm{ME}_{m}+\frac{\mathrm{RE}}{k_{f}}
\end{aligned}
$$

In all cases it is assumed that the maintenance requirement only depends on the weight of the animal, and no consideration is given to the influence of feeding intensity, sex or genotype ; the English report mentions that there probably is a difference between the sexes, but no account is taken of this. This possible source of error will not appear in cases where the standards are based on feeding trials. A comparison between the equations for calculating the maintenance requirements (MJ) in Holland, UK, Ireland and Sweden shows the following :

\begin{tabular}{lcc}
\hline & $\begin{array}{r}\text { Liveweight of animal } \\
\text { (kg) }\end{array}$ \\
\hline Holland & 200 & 400 \\
UK & 27 & 41 \\
Ireland & 28 & 45 \\
Sweden & 23 & 47 \\
\hline
\end{tabular}

The English and Irish figures include a so-called safety-margin of 5 per cent, the Dutch figures one of 10 per cent.

Data on the energy deposition in growing animals are scarce, and the reliability of the formulae given in table 2 must be judged accordingly. This is also the reason why in Holland the final standards include some corrections according to results obtained in feeding trials. These include corrections relating both to differences in weight and in animal production level. In France full account has been taken of these discrepancies between the factorial method and the feeding trials combined with comparative slaughterings, and it is on the basis of the latter that the relationship between energy requirement (intake), the liveweight and liveweight gain has been established. The situation for Switzerland is similar.

When the standard for energy allowance is expressed in metabolisable energy, as in UK, Ireland and Sweden, the requirement figures for the same animal will vary with the energy concentration of the ration. As the concentration goes down, the requirement expressed in ME increases. It is inevitable that, for the farmer, this makes the system more difficult to apply; it complicates the comparisons between feeds, both in relation to their 'productive' value and, as a consequence of this, also in relation to a realistic price setting procedure. Take as an example the system of the UK : in order to predict production, it is necessary to consult three different tables (ME system for performance prediction), and three other tables must be consulted in order to work out a ration (variable net energy system). We may expect that the importance of these draw-backs 


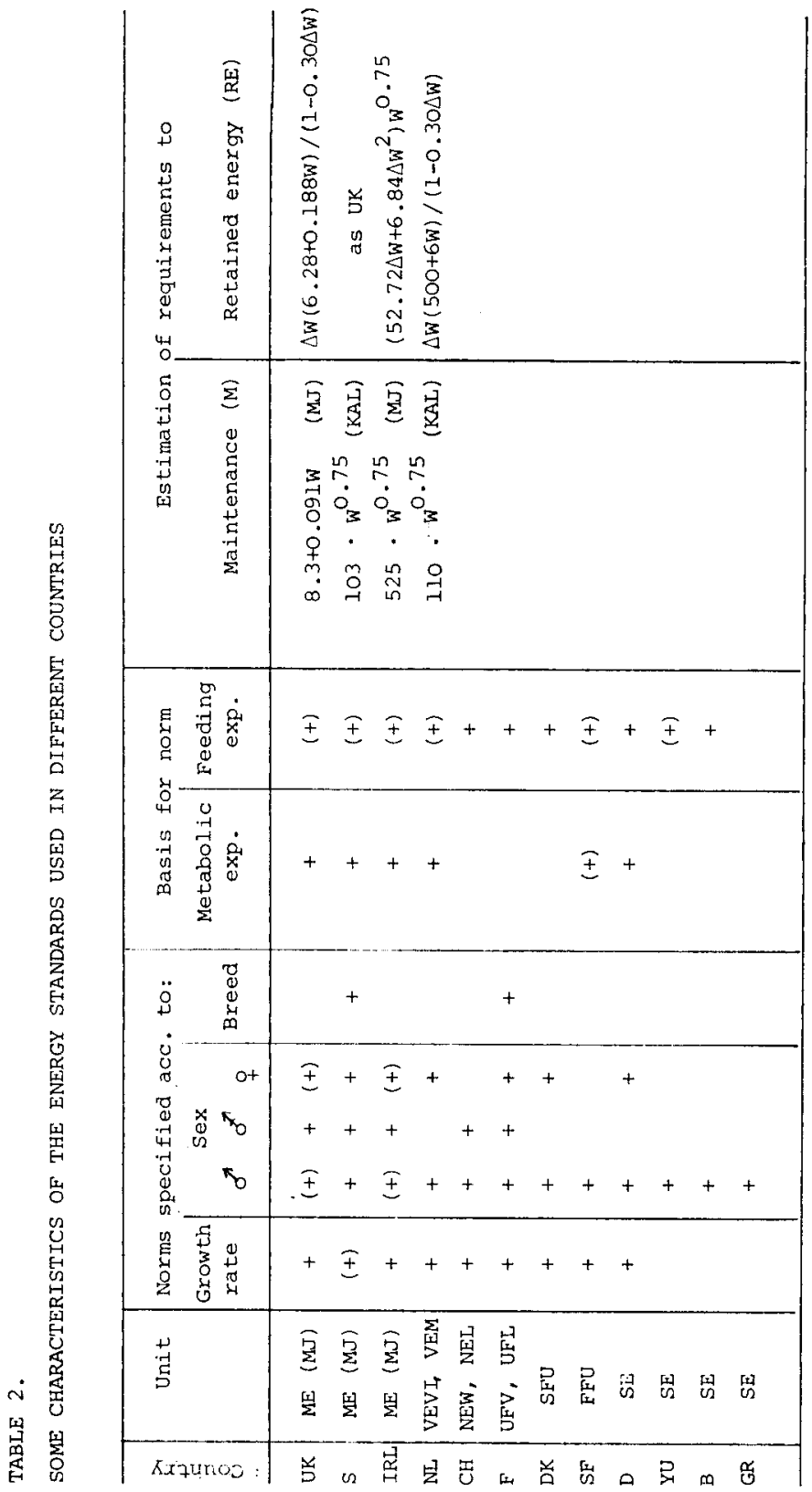


will be less in the future when the use of Electronic Data Processing, as a tool in feed rationing, becomes more widespread.

As seen from table 2, a majority of the countries based their norms mainly, or exclusively, on feeding experiments. The reports do not give information on the size of the experimental material, nor on the magnitude of variation in the daily energy allowances which has been applied.

\section{Conclusions}

The survey of the reports on energy feeding standards applieds to beef cattle, which were received from 12 COST-countries, reveals that many old and new systems are in use. Even in cases where the same basic system are applied, each country usually 'adapts' the system in one way or another. The scientific justification for many of the diversities seems scarce in some cases, and it is tempting to think that they are attributable to a kind of national tradition or prestige. The lack of agreement between the feeding standards, from country to country, has many unfortunate practical and scientific consequences, as mentioned in my introduction. It seems obvious that we have an area here where more efforts towards harmonisation would be very appropriate.

\section{References}

Vermorel M., 1978. Feed evaluation for ruminants. II The new energy systems proposed in France. Livest. Prod. Sci. 5, 347-365.

STEg A., VAN DeR Honing Y., 1979. Relationships between energy values predicted with several feed evaluation systems for dairy cows. Report no. 49. IVVO Lelystad, NI. 